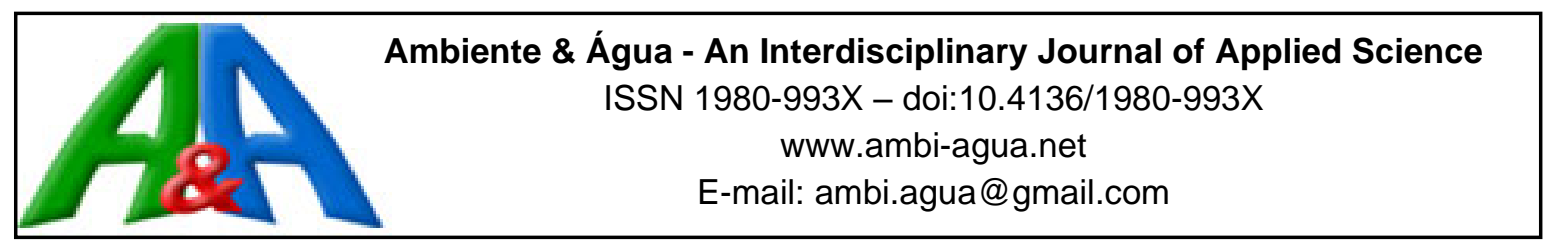

\title{
Application of the SWAT hydrological model in flow and solid discharge simulation as a management tool of the Indaia River Basin, Alto São Francisco, Minas Gerais
}

\author{
ARTICLES doi:10.4136/ambi-agua.2694
}

Received: 12 Jan. 2021; Accepted: 03 May 2021

\author{
Kauem Simões ${ }^{1,2(1)}$; Rita de Cássia Cerqueira Condé ${ }^{1,3(D ;}$; \\ Henrique Llacer Roig ${ }^{1}$; Rejane Ennes Cicerelli $^{1 *(D)}$

\begin{abstract}
${ }^{1}$ Instituto de Geociências. Programa de Pós-Graduação em Geociências Aplicadas e Geodinâmica. Universidade de Brasília (UnB), Campus Universitário Darcy Ribeiro, CEP: 70910-900, Brasília, DF, Brazil. E-mail: kauem2001@gmail.com,rita.piscoya@ana.gov.br, roig@unb.br ${ }^{2}$ Companhia de Desenvolvimento dos Vales do São Francisco e Parnaíba (CODEVASF/DF), SGAN 601, Módulo I, Edifício Deputado Manoel Novaes, CEP: 70830-019, Brasília, DF, Brazil. E-mail: kauem2001@gmail.com

${ }^{3}$ Agência Nacional de Águas e Saneamento Básico (ANA), Setor Policial, área 5, Quadra 3, s/n, CEP: 70610-200, Brasília, DF, Brazil. E-mail: rita.piscoya@ana.gov.br

*Corresponding author. E-mail: rejaneig@unb.br
\end{abstract}

\begin{abstract}
Measurement and evaluation of soil erosion and consequent sediment yield are fundamental in the planning and management of watersheds, as they allow the identification of critical areas susceptible to erosive processes. This study analyzed the sediment yield generated by water erosion in the Indaia River Basin, Alto São Francisco, Minas Gerais, by using the SWAT hydrological model. From a regional/local scale, the initial simulation of the variables (flow and solid discharge) was performed on a monthly scale from 1988 to 2017. Then, parameter-sensitivity analysis, calibration, and validation of the model were executed. In the monthly calibration (1988 to 2007), the performance of the simulations for flow was $\mathrm{R}^{2}=0.92$ and NSE $=0.91$ and for total solid discharge $\mathrm{R}^{2}=0.51$ and $\mathrm{NSE}=0.50$. In the monthly validation (2008 to 2017) for flow, $\mathrm{R}^{2}=0.85$ and NSE $=0.82$ was obtained and for total solid discharge $\mathrm{R}^{2}=0.19$ and NSE $=0.16$. Despite the unsatisfactory result in the validation stage, the model was able to analyze the distribution of sediment production by sub-basins or even by the Hydrologic Response Unit (HRU). Therefore, a sediment-yield map was generated which qualitatively indicated a tendency for greater erosive processes in the central portion of the basin. The results will support public policies mitigating environmental degradation of the Indaia River Basin.
\end{abstract}

Keywords: calibration and validation of models, sediment yield, sensitivity analysis, water erosion.

\section{Aplicação do modelo hidrológico SWAT na simulação de vazão e descarga sólida como instrumento de gestão da bacia hidrográfica do rio Indaiá, Alto São Francisco, Minas Gerais}

\section{RESUMO}

A mensuração e avaliação da erosão do solo e, consequentemente, da produção de sedimentos são fundamentais no planejamento e gestão de bacias hidrográficas, pois permitem 
a identificação de áreas críticas susceptíveis aos processos erosivos. Assim, o objetivo deste estudo foi analisar a produção de sedimentos gerada por erosão hídrica na bacia do rio Indaiá, Alto São Francisco, Minas Gerais, aplicando o modelo hidrológico SWAT. De posse de uma base de dados (espaciais e alfanuméricos), realizou-se a simulação inicial das variáveis (vazão e descarga sólida) em escala mensal no período de 1988 a 2017. Em seguida, executou-se a análise de sensibilidade dos parâmetros, a calibração e a verificação do modelo. Na calibração mensal (1988 a 2007), o desempenho das simulações para vazão foi $\mathrm{R}^{2}=0,92$ e NSE=0,91, e para descarga sólida total $\mathrm{R}^{2}=0,51$ e NSE=0,50. Já na verificação mensal (2008 a 2017) para vazão foi obtido $R^{2}=0,85$ e NSE $=0,82$, e para descarga sólida total $R^{2}=0,19$ e $N S E=0,16$. Apesar deste resultado insatisfatório na etapa de validação, foi possível analisar a distribuição da produção de sedimentos por sub-bacias ou mesmo por Unidade de Resposta Hidrológica. Dessa forma, gerou-se um mapa de produção de sedimentos que indicou, de forma qualitativa, uma tendência de ocorrência de maiores processos erosivos na porção central da bacia. Espera-se que os resultados gerados apoiem às políticas públicas mitigadoras da degradação ambiental da bacia do rio Indaiá.

Palavras-chave: análise de sensibilidade, calibração e verificação de modelos, erosão hídrica, produção de sedimentos.

\section{INTRODUCTION}

Characterization, measurement, and evaluation of soil erosion and consequent sediment yield are fundamental for effective planning and management of watersheds. Such analyses allow the identification of critical areas susceptible to erosive processes and the implementation of appropriate soil management and conservation practices known as Best Management Practices (BMPs), thus contributing to the control of environmental degradation by reducing sediment and nutrient losses (Briak et al., 2019; Himanshu et al., 2019).

Currently, the monitoring of sediment loads is carried out punctually through hydro sedimentological stations located in or near the basin, and generally only four measurements are taken per year of suspended solid discharge (Carvalho, 2008). However, it is expensive and impractical to monitor a watershed "in loco".

For this reason, since the 1940s mathematical simulation models have been developed to represent in a simplified way the physical phenomena of nature, whether they are empirical, conceptual, or physically based (Devia et al., 2015). Among the various hydrological models that consider the physical processes occurring in the basin, the Soil and Water Assessment Tool (SWAT) is the most used because it is friendly and its interface is coupled to the geographic information system (SIG). It is also easily linked to sensitivity, calibration, and uncertainty analysis tools as SWATCUP (Van Griensven et al. 2012; Devia et al., 2015). SWAT is a semidistributed hydrological model drawing of continuous simulations in time (yearly, monthly, daily, and more recently in the sub-daily) (Boithias, et al., 2017; Brighenti et al., 2019b), mainly to simulate and predict the water discharge in a basin by generating scenarios (Neitsch et al., 2011; Gassman and Yingkuan, 2015, Krysanova and White, 2015).

This tool was developed by the United States Department of Agriculture (USDA) in partnership with Texas A\&M University (TAMU) (Arnold et al., 2012a) to simulate various physical processes in the scale of watersheds, sub-basins, hydrological response units (HRUs), rivers (river reaches). It also has been frequently used to predict and evaluate the impacts caused by anthropic actions (changes in land use and coverage) and/or climate change on water balance, sediment yield, and water quality, and can be used in the assessments of land and agricultural management impacts (Francesconi et al., 2016).

The SWAT hydrological model has been evaluated by several researchers worldwide for 
runoff (Pandey et al., 2015; Tiwari et al., 2018; Upadhyay et al., 2019), sediment load (Vigiak et al., 2015; 2017; Himanshu et al., 2017; 2019; Duru et al., 2018; Brighenti et al., 2019a) and nutrient simulations (Malagó et al., 2017; Qiu et al., 2018; Uribe et al., 2018; Pulighe et al., 2020), and satisfactory model performance was reported. SWAT was used in the identification of critical erosion-prone areas in watersheds (Himanshu et al., 2019; Pulighe et al., 2020) and to respond to total suspended solids (TSS) load affecting climate change scenarios (Tan et al., 2019; Khoi et al., 2020).

Specifically, in Brazil in the last 5 years, several studies have been developed using SWAT with a focus on soil erosion and sediment loads, including the studies of Bonumá et al. (2014), Creech et al. (2015), Dantas et al. (2015), Silva et al. (2016; 2017; 2018a; 2018b) and Condé (2021). Overall, all these previous investigations identified inconsistencies in the estimation of variables related to sedimentological processes (e.g. solid discharge, sediment yield, the concentration of suspended sediments), demonstrating the complexity in such modeling.

Therefore, in this study we analyzed the sediment yield generated by water erosion in the Indaia River Basin, Alto São Francisco, state of Minas Gerais (MG), from 1988 to 2017, applying the SWAT hydrological model. The Indaia River Basin is located in a very critical region concerning soil erosion and sediment production, the Alto São Francisco. It is an important contributor to the Três Marias Reservoir, which in turn has a significant regularization function of the São Francisco River flow. There are few studies on soil erosion and sediments developed in the basin, highlighting the following works: Macêdo (2009), Menezes (2013), and Pinto et al. (2014). However, none of these works used a physically based model to understand the sediment yield and the impact on the land use of this process. Thus, the main motivation of this work was to develop a calibrated model, based on a robust dataset that identified the areas most prone to erosive processes in the Indaia River Basin, supporting the decision-making of public policy to combat environmental degradation in the study area.

\section{MATERIAL AND METHODS}

\subsection{Study Area}

The Indaia River Basin is located in the São Francisco River Basin, state of Minas Gerais, southeastern Brazil, upstream of the Três Marias Hydroelectric Plant Reservoir. (Figure 1).

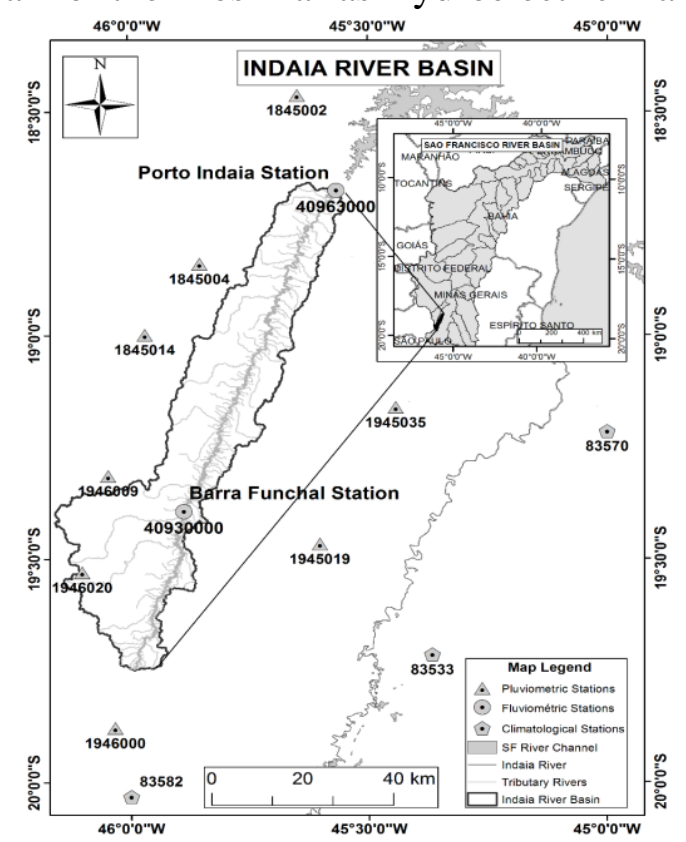

Figure 1. Study area with the localization of fluviometric, climatological and pluviometric stations. 
The Indaia River is one of the main tributaries of the São Francisco River in Minas Gerais, which, together with the Abaete, Borrachudo, Para and Paraopeba Rivers, form the Upper São Francisco Basin. It is a 6th order basin, with an area of approximately $2,300 \mathrm{~km}^{2}$ and a length of about $262 \mathrm{~km}$, rising in the municipality of Corrego Danta-Minas Gerais at the elevation of $1170 \mathrm{~m}$, and disemboguing into the Três Marias Reservoir, whose operation is under the control of "Companhia Energética de Minas Gerais" (CEMIG) (Macêdo, 2009).

Two climatic types are found in the region, according to the Köppen classification: Cwa humid temperate climate with dry winter and hot summer; Aw - tropical climate with dry winter and rainy summer. The region has high rainfall rates, with values ranging between 1,000 and $2,000 \mathrm{~mm}$ annually, the average temperature around $23^{\circ} \mathrm{C}$, average annual sunshine of 2,400 hours, average annual evaporation of $1,000 \mathrm{~mm}$, and average annual relative humidity around 70 to $80 \%$, with the highest values occurring in the highest altitude areas (Brasil, 2006).

Cambisols $( \pm 59 \%)$, red oxisols $( \pm 21 \%)$, and litholic neossols $( \pm 19 \%)$ predominate in the basin area, with a less significant occurrence of red yellow oxisol $(<1 \%)$. The Indaia River Basin is a rural basin, located in the Cerrado biome (Brazilian Savanna), where the following classes of land use and cover stand out: Gallery Forest $( \pm 37 \%)$; Savanna $( \pm 13 \%)$, Field $( \pm$ $11 \%)$, Agriculture and Pasture $( \pm 39 \%)$, and presence of bodies of water $( \pm 1 \%)$ (MapBiomas, 2018). In the Indaiá Basin, $34 \%$ of the area has flat to smooth wavy relief, $10 \%$ wavy relief, and $56 \%$ wavy, mountainous, or rugged relief.

\subsection{Hydrological and Sedimentological Modeling}

The methodological procedures started with the selection of the input data required by the SWAT. The spatial data were pre-processed in ArcGIS for compatibility and integration of these, transforming them into the raster format, with a spatial resolution of 30 meters, metric plane coordinates in the UTM projection system (Universal Transverse Mercator), Zone 23 South, datum SIRGAS 2000 (Geocentric Reference System for the Americas), and scale 1:250,000. The spatial database of the study area was composed of the following maps:

- Digital Elevation Model (DEM): SRTM / NASA, base year 2014 - spatial resolution of 30 meters;

- Solo Map: RadamBrasil / IBGE, base year 1987;

- Land Use and Coverage Map: MapBiomas, base year 2007 - spatial resolution of 30 meters (Mapbiomas, 2018).

Alphanumeric data (climate, precipitation, flow, sediments, soil parameters, parameters of land use and cover) were first edited, tabulated, and organized according to the ArcSWAT standard. The alphanumeric database was then composed of:

- Weather Data: Historical series of daily data of maximum/minimum surface temperature (degrees Celsius), solar radiation $\left(\mathrm{MJ} / \mathrm{m}^{2}\right)$, average wind speed $(\mathrm{m} / \mathrm{s})$, and relative air humidity (\%), of 3 (three) conventional climatological stations of the "Instituto Nacional de Meteorologia" (INMET) located close to the Indaia River Basin (Figure 1), from 1988 to 2017.

- Pluviometric data: Historical series of daily rainfall data $(\mathrm{mm})$, from 9 (nine) pluviometric stations of the "Agência Nacional de Águas" (ANA), located near the Indaia River Basin (Figure 1), from 1988 to 2017.

- Fluviometric data: Historical series of daily flow data $\left(\mathrm{m}^{3} / \mathrm{s}\right)$, from 2 (two) fluviometric stations, Barra do Funchal (ANA) located in the central part of the basin and Porto Indaia (CEMIG) located in the basin outflow (Figure 1), from 1988 to 2017. 
- Sedimentometric data: Daily sample data of suspended sediment concentration (mg/L) from the Porto Indaia sedimentometric station (CEMIG), from 1974 to 2013 (data available).

For parameterization of the SWAT, an adaptation of the original MDB was performed to the local reality of the study region, with new values of physical and chemical properties of soils and land use and cover. In addition to statistical weather parameters. The parameters were adapted on the following SWAT bases:

- UserSoil: parameters of the physical and chemical properties of the soil profiles.

- Crop: vegetation growth parameters for each type of use and land cover.

- Wgen: statistical climate parameters needed to use the SWAT climate generator.

Regarding the values of the parameters of the UserSoil and Crop databases, these were obtained from the literature according to Table 1. Meaning of each parameter see Neitsch et al. (2011).

The statistical parameters of the Wgen climate database were obtained with the tools available on the SWAT official website (WeatherDatabase and PcpSTAT), which use basic information from the climatological and pluviometric stations existing in the study region to calculate the climatic statistical data.

The first processing performed by ArcSWAT is related to watershed delineation by selecting the outlet point. In a watershed delineation, sub-basins are created by subdivision of the watershed from the DEM map. Watershed Delineation tools define multiple hydrologically connected sub-watersheds within a given study area.

After subdividing the basin into 14 sub-basins, the next step was the insertion of soil maps, land use and cover, and slope. The slope map was created through processing on the DEM after defining 3 (three) slope classes: from 0 to $8 \%$, from 8 to $20 \%$, and values above $20 \%$.

Hydrologic Response Units (HRUs) were then created, which correspond to homogeneous polygons with the same characteristics of soil, land use and cover, and slope (Arnold et al., 2012a). 471 HRUs were generated in this work.

Regarding the equations performed, the hydrological cycle simulated by the SWAT was based on the water balance equation (Neitsch et al., 2011). The CN-SCS method (USDA, 1972) was used to calculate the runoff. The Penman-Monteith method (Penman, 1948; Monteith, 1965) was used to calculate evapotranspiration. The Muskingum Method (Brakensiek, 1967) was selected for the routing of water in the river channel, considering its degradation, and the Bagnold Simplified Equation (Bagnold, 1977) for the transport of sediments in a river.

According to guidelines by Arnold et al. (2012b), the model's warm-up period was 3 years, from $01 / 01 / 1985$ to $12 / 31 / 1987$. The simulation period, on the other hand, was based on 30 years of observations, from 01/01/1988 to $12 / 31 / 2017$, defined based on climatological data existing in the study region. For calibration, the period of 20 years was considered, from $01 / 01 / 1988$ to $12 / 31 / 2007$, due to the pluviometric and fluviometric data being only in that period. For the validation, 10 years were considered, from 01/01/2008 to 12/31/2017.

After insertion of the input data (climatological and rainfall), was performed in the ArcSWAT the initial simulation of the flow and solid discharge variables on the monthly scale.

The sensitivity analysis and calibration were performed concurrently and semiautomatically in the SWAT-CUP software, which has several built-in optimization algorithms, such as SUFI2 (Sequential Uncertainty Fitting Algorithm Version 2), GLUE (Generalized Likelihood Uncertainty Estimation), PARASOL (Parameter Solution), PSO (Particle Swarm Optimization), MCMC (Markov Chain Monte Carlo). 
Table 1. Parameters of the UserSoil and Crop databases.

\begin{tabular}{cc}
\hline & Usersoil database parameters \\
\hline Parameter & Reference \\
\hline SOL_ZMX & \\
SOL_CBN & \\
CLAY & Brasil (1987) for Cambisols, red oxisols and red yellow oxisol, and Baldissera (2005) for litolic neossol \\
SILT & \\
SAND & \\
ROCK & \\
SOL_ZMX & \\
SOL_CBN & \\
CLAY & \\
SILT & \\
ANION_EXCL & \\
SOL_CRK & Ferrigo (2014) for Cambisols, red oxisols and red-yellow oxisol, and Baldissera (2005) for litolic \\
TEXTURE & neossol. \\
SOL_BD & \\
SOL_AWC & \\
SOL_K & \\
SOL_ALB & \\
USLE_K & \\
\hline
\end{tabular}

\begin{tabular}{|c|c|}
\hline \multicolumn{2}{|r|}{ Crop database parameters } \\
\hline Parameter & Reference \\
\hline $\begin{array}{c}\text { BIO_E } \\
\text { BLAI } \\
\text { FRGRW1 } \\
\text { LAIMX1 } \\
\text { FRGRW2 } \\
\text { LAIMX2 } \\
\text { DLAI } \\
\text { T_BASE } \\
\text { GSI } \\
\text { VPDFR } \\
\text { CN } \\
\text { ALAI_MIN }\end{array}$ & $\begin{array}{l}\text { Strauch and Volk (2013) for classes of Gallery Forest (MATA), Savanna (CERR) e Field (CAMP), and } \\
\text { default values for classes of Pasture (PAST), silviculture (EUCA), Annual Cultures (AGRL), Semi- } \\
\text { Perennial Cultures (SUGC), and Bodies of Water (WATR). }\end{array}$ \\
\hline $\begin{array}{c}\text { HVSTI } \\
\text { CHTMX } \\
\text { RDMX } \\
\text { T_OPT } \\
\text { CNYLD } \\
\text { CPYLD } \\
\text { BN1 } \\
\text { BN3 } \\
\text { BP1 } \\
\text { BP2 } \\
\text { BP3 } \\
\text { WSYF } \\
\text { USLE_C } \\
\text { FRGMAX } \\
\text { WAVP } \\
\text { CO2HI } \\
\text { BIOEHI } \\
\text { RSDCO_PL } \\
\text { OV_N } \\
\text { BIO_LEAF } \\
\text { MAT_YRS } \\
\text { BMX_TREES } \\
\text { EXT_COEF } \\
\text { BM_DIEOFF }\end{array}$ & $\begin{array}{l}\text { Ferrigo (2014) for classes of Gallery Forest (MATA), Savanna (CERR) and Field (CAMP), and default } \\
\text { values for classes of Pasture (PAST), silviculture (EUCA), Annual Cultures (AGRL), Semi-Perennial } \\
\text { Cultures (SUGC), and Bodies of Water (WATR) }\end{array}$ \\
\hline
\end{tabular}


In this work, the optimization algorithm SUFI-2 was chosen, since it is the mostrecommended algorithm, especially due to its computational efficiency and good performance (Wu and Chen, 2015). The SUFI-2 uses the Latin hypercube method to define the parameters, and the process starts with a range of values determined by the user (Abbaspour, 2015). As the SWAT-CUP provides a vast list of parameters (651 parameters) that the user can choose, and to rationalize the procedures, it was necessary to previously select a set of more sensitive parameters to be used in sensitivity analysis and calibration.

For this, a bibliographic review was performed that prioritized hydrological modeling works, whose study areas were in the Cerrado Biome, to indicate parameters with behavior similar to the study area of the present work (Baldissera, 2005; Strauch and Volk, 2013; Fernandes, 2015; Castro et al., 2016; Nunes, 2016). In all, 26 parameters were selected to be used in the sensitivity analysis, calibration and validation of the model.

Hydrology (flow) and sediments (total solid discharges) were modeled together, and all steps of calibration and validation of the model were performed on a monthly scale.

In general, the results provided by the SWAT-CUP for sensitivity are given based on the generated values of t-stat and p-value. The t-stat provides the average sensitivity in which the higher the absolute value, the greater the sensitivity of the parameter. The p-value determines the significance of the sensitivity, in which values close to zero ( $p$-value $<0.05$ ) indicate greater significance (Abbaspour, 2015b).

In the calibration step, to represent the effects of the uncertainties of the input parameters, SUFI2 quantifies the adjustment between the simulation result, expressed with a 95\% uncertainty prediction (95PPU), and the observation, expressed as a single signal (with some error associated with it), by estimating two statistics: P-factor and R-factor. The P-factor is the percentage between the measured data and the $95 \%$ prediction uncertainty range (95PPU). The $\mathrm{R}$-factor is the ratio between the width of this 95PPU range and the standard deviation of the observed data. The quality adjustment and calibration uncertainty are examined at each iteration by the balance between the P-factor and R-factor. There are no exact numbers that express the best value for both factors. For flow simulations, a P-factor greater than $70 \%$ and an R-factor close to 1 (one) is allowed. For sediment, a smaller P-factor and a larger R-factor could be acceptable (Abbaspour et al., 2015b).

Objective functions were also used in calibration and validation, which are equations that determine the deviation between the output values of the model and observed data. These are the metrics used by the optimization algorithms to determine the quality and efficiency of the simulation, that is, how far the new simulation is from the original simulation or the observed data. The objective functions used in this work were: NSE (Nash-Sutcliffe Efficiency), $\mathrm{R}^{2}$ (Coefficient of Determination) and PBIAS (Percent Bias).

The monthly simulated flows were calibrated (1988-2007) and validated (2008-2017) based on the values observed flows (monthly averages) of the two (2) fluviometric control stations: Barra do Funchal (ANA) located in the central part of the basin and Porto Indaia (CEMIG) located in the outlet of the watershed (Figure 1).

The monthly simulated total solid discharges were calibrated (1988-2007) and validated (2008-2017) based on the values of the total solid discharges obtained by applying a ratio of $10 \%$ of solid bottom discharge and $90 \%$ of solid suspended discharge, with the total solid discharge equaling the sum of the two discharges, as explained by Carvalho (2008).

Solid suspended discharges were determined using a potential equation generated by a sediment rating curve based on the suspended sediment concentration samples $(\mathrm{mg} / \mathrm{L})$ collected from the Porto Indaia sedimentometric station (1985-2013). The sediment rating curve was needed to fill the gap in the temporal sequence of sediment data.

In the calibration step, five iterations of 500 simulations were performed until a satisfactory result was obtained, each simulation being run monthly for 20 years (1988-2007). 
In the validation step, one (1) iteration of 500 simulations was performed using the best parameter ranges obtained in the 3rd round of calibration (iteration 3), each simulation being run monthly for 10 years (2008-2017).

In the calibration and validation at the end of each iteration, the graphic output generated by SWAT-CUP was analyzed: graphs of the variables of interest (flow and total solid discharge) with the measured and simulated values versus time. The values of the objective functions $\left(\mathrm{R}^{2}\right.$, NSE and PBIAS) and the values of the statistics that measure the uncertainties of the parameters (P-factor and p-value) were also evaluated, as well as the amplitude of the new intervals generated for the parameters.

Through the calibrated hydrological and sedimentological model, the annual sediment yield values (ton/ha.year) of each sub-basin were obtained for the years 1988 and 2007, as well as the annual average of 20 years (1988 to 2017). A map of the distribution of the annual average sediment yield of the Indaia river basin by HRU was then drawn up and analyzed.

\section{RESULTS AND DISCUSSION}

The initial and final values of the parameters related to the monthly calibration (19882007) as well as the results of the sensitivity analysis are shown in Table 2.

Table 2. Parameter values and sensitivity analysis.

\begin{tabular}{|c|c|c|c|c|}
\hline \multirow{2}{*}{ *Parameter } & \multirow{2}{*}{ Initial Value } & \multirow{2}{*}{ *Final Value } & \multicolumn{2}{|c|}{ Sensitivity } \\
\hline & & & t-stat & p-value \\
\hline GW_REVAP & 0.02 & $\mathrm{~V}: 0.19$ & 3.71 & 0.00 \\
\hline SOLL_K & 0.0 & R:-0.56 & -3.51 & 0.00 \\
\hline GWQMN & 0.0 & $V: 3223.47$ & 3.18 & 0.00 \\
\hline USLE_P & 0.0 & $\mathrm{R}:+0.33$ & 3.39 & 0.00 \\
\hline SHALLST & 0.0 & $V: 1341.90$ & -2.54 & 0.01 \\
\hline USLE_K & 0.0 & $\mathrm{R}:+0.37$ & 1.97 & 0.04 \\
\hline $\mathrm{CN} 2-\overline{2}$ & 69.0 & R:-0.09 & 1.76 & 0.07 \\
\hline CH_K2 & 0.0 & $V: 124.54$ & 1.61 & 0.10 \\
\hline SLSUBBBSN & 10 & R:-0.004 & -1.61 & 0.10 \\
\hline SPCON & 0.0001 & V:0.004 & 1.33 & 0.18 \\
\hline CH_N2 & 0.0 & $\mathrm{~V}: 0.17$ & -1.24 & 0.21 \\
\hline SURLAG & 0.05 & $\mathrm{~V}: 1.39$ & 1.22 & 0.22 \\
\hline ADJ_PKR & 0.5 & $V: 0.67$ & -1.21 & 0.22 \\
\hline PRF & 0.0 & V:1.97 & 1.04 & 0.29 \\
\hline SOL_AWC & 0.0 & $\mathrm{R}:+0.11$ & -0.95 & 0.34 \\
\hline ALPH̄A_BF & 0.0 & $\mathrm{~V}: 0.70$ & -0.69 & 0.48 \\
\hline REVAPMN & 0.0 & $\mathrm{~V}: 435.95$ & 0.63 & 0.52 \\
\hline RCHRG_DP & 0.0 & $\mathrm{~V}: 0.25$ & -0.60 & 0.54 \\
\hline LAT_SEDD & 0.0 & $\mathrm{~V}: 1.53$ & 0.50 & 0.61 \\
\hline SPEXP & 1.0 & $\mathrm{~V}: 1.2421$ & -0.45 & 0.64 \\
\hline ESCO & 0.0 & $\mathrm{~V}: 0.21$ & 0.39 & 0.69 \\
\hline CH_COV1 & 0.0 & V:0.47 & 0.34 & 0.73 \\
\hline USLEE_C & 0.001 & $\mathrm{R}:+0.09$ & 0.32 & 0.74 \\
\hline CH_COV2 & 0.0 & V:0.62 & -0.09 & 0.92 \\
\hline GWHT & 0.0 & $\mathrm{~V}: 19.05$ & 0.04 & 0.96 \\
\hline GW_DELAY & 0.0 & $V: 32.52$ & -0.02 & 0.97 \\
\hline
\end{tabular}

*Meaning of each parameter see Neitsch et al. (2011). *R (relative): the value of the initial parameter is multiplied by 1 + (calibrated value); V (replace): the initial value is replaced by the given value. 
Analyzing the t-stat and p-value values provided by SWAT-CUP (Table 2), it was found that the 5 (five) parameters that most influenced the flow estimate results were GW_REVAP, SOL_K, GWQMN, SHALLST, and CN2, with p-value values ranging from 0.00 to 0.07 . It can be inferred from the results that the parameters associated with groundwater flow (GW_REVAP, GWQMN AND SHALLST) were significant in the model. These parameters are related to the amount of water that moves in the soil zone in response to water deficiencies and the depth of the water level in the shallow aquifer.

The five (5) parameters that most influenced the results of the estimate of the total solid discharge were USLE_P, USLE_K, SLSUBBSN, SPCON, and ADJ_PKR with p-value values ranging from 0.00 to 0.22 . The first three (3) parameters are related to the Modified Soil Loss Universal Equation (MUSLE) used in the SWAT, specifically with the conservationist practices factor (P), soil erodibility factor (K), and topographic factor (LS). The other two (2) parameters are related to sediment transport in the main channel and the tributary channels.

\subsection{Calibration and Validation}

The hydrological and sedimentological calibrations were performed from 1988 to 2007 (20 years). The graphs of the historical series of the average monthly flows (simulated and observed), resulting from the best simulation obtained in the monthly calibration, can be seen in the following figures: Porto Indaia Station and Barra do Funchal Station (Figure 2).
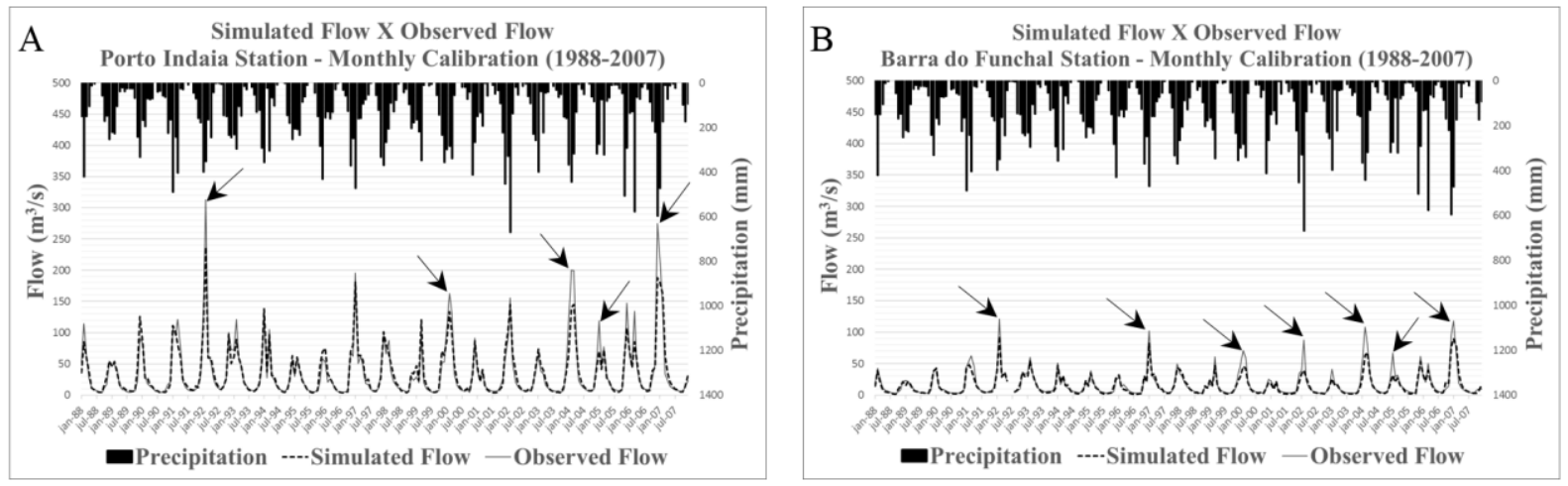

Figure 2. Better flow simulation in calibration - Porto Indaia Station (a) and Barra do Funchal Station (b).

It is observed in Figure 2 that the simulated flow results were represented satisfactorily along with the historical monitoring series, mainly in periods of drought, where the base flow was well adjusted, presenting values greater than zero during the recession period. However, in some periods of the series, such as the years 1992, 1997, 2000, 2002, 2004, 2005 and 2007, there is a tendency for simulation to underestimate the runoff in the rainy months (peaks), with simulated flow values lower than observed flows.

A better adjustment of the simulation is observed in the Porto Indaia fluviometric station (Figure 2-a) compared to the Barra do Funchal station (Figure 2-b), which can be explained in part by the climatic variability in the basin. The long period for calibration is used to balance the influences of the dry and humid periods caused by climate parameters (Choubin et al., 2019). Thus, it is assumed that 20 years of monthly simulated flows (1988-2007) used in the calibration process were satisfactory for estimation. The graph of the historical series of the monthly total solid discharges (Qst simulated and observed) at the Porto Indaia Station, resulting from the best simulation obtained in the monthly calibration, can be seen in Figure 3 .

It is observed in Figure 3 that in practically all periods of the series the observed data of total solid discharge were slightly smaller than the simulated data. In these years, solid discharge has been overestimated. However, there are exceptions where the solid discharge was 
underestimated, such as the peaks of 1992, 1997, 2000, 2006 and 2007, corresponding to years of heavy rainfall.

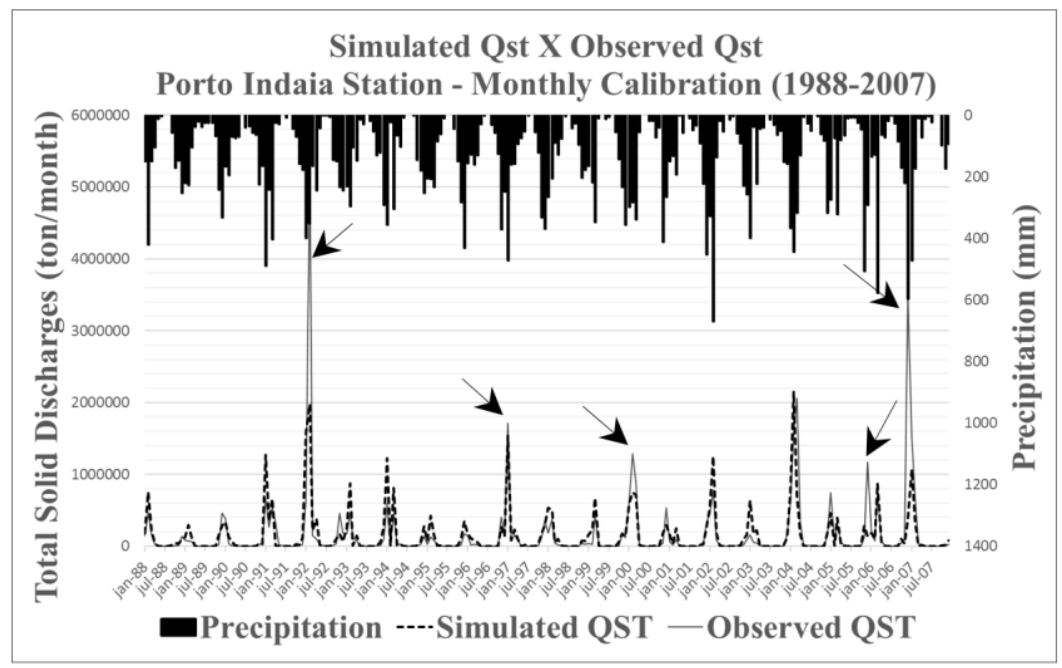

Figure 3. Better total solid discharge (QST) simulation in calibration - Porto Indaia Station.

Analyzing the results of the statistical analysis of the modeling in the step of monthly calibration for 5 iterations of 500 simulations, it was verified that the 3 rd calibration iteration presented the best result. In this iteration, the following performance indexes for the simulation of the flow variable were obtained: Porto Indaia Station (P-factor $=0.96, \mathrm{R}$-factor $=0.98, \mathrm{R}^{2}=$ 0.92, NSE $=0.91$ and PBIAS $=1.9$ ) and Barra do Funchal Station $(\mathrm{P}$-factor $=0.95$, R-factor $=$ $0.88, \mathrm{R}^{2}=0.90, \mathrm{NSE}=0.87$ and PBIAS $\left.=12.5\right)$, and variable total solid discharge: Porto Indaia Station $\left(\mathrm{P}\right.$-factor $=0.78$, R-factor $=0.74, \mathrm{R}^{2}=0.51$, NSE $=0.50$ and PBIAS $=5.6$ ).

It was observed that $\mathrm{R}^{2}$ and NSE improved with the iterations, unlike the P-factor and Rfactor. As a P-factor> 0.7 and a R-factor close to 1.00 (one) are recommended, the 3rd calibration iteration was defined as the best result.

According to Moriasi et al. (2007), the NSE values obtained in the monthly calibration indicate that the model satisfactorily simulates the flow and the total solid discharge.

The hydrological and sedimentological validation was performed from 2008 to 2017 (10 years). A validation of 500 simulations was performed using the parameter ranges obtained in the 3rd calibration iteration (best result).

The graphs of the historical series of monthly average flows (simulated and observed), resulting from the simulation obtained in the monthly validation, can be seen in the following figures: Porto Indaia Station (Figure 4-a) and Barra do Funchal Station (Figure 4-b).
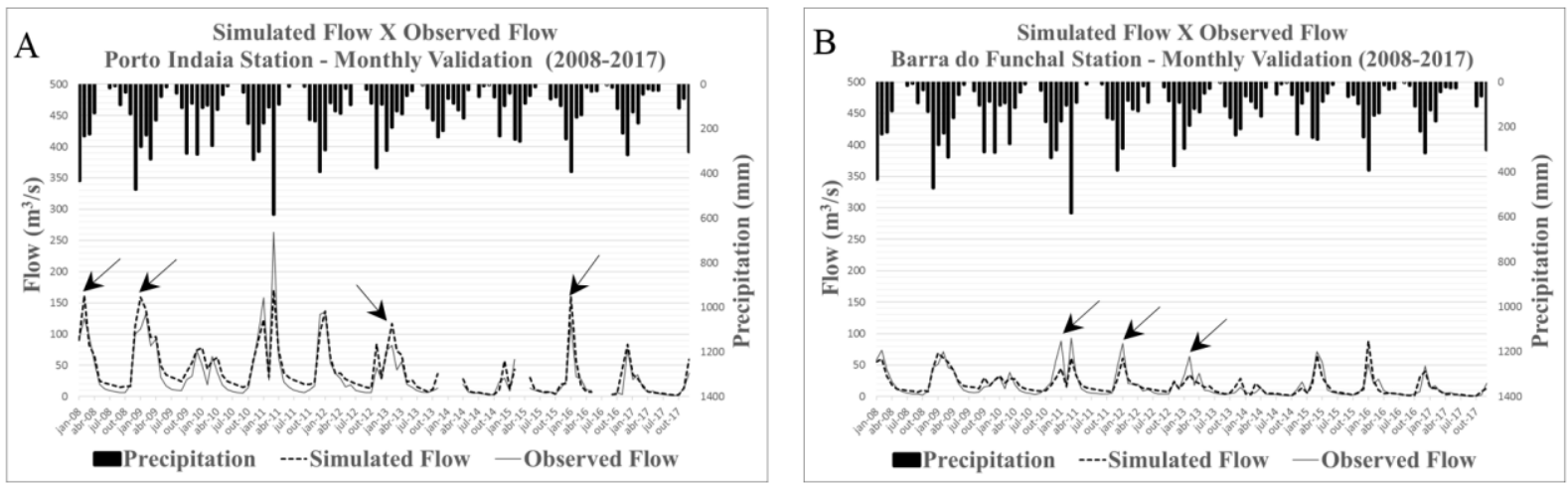

Figure 4. Flow simulation in validation - Porto Indaia Station (a) and Barra do Funchal Station (b). 
It is observed in the two figures (Figure 4-a and Figure 4-b) that the results of the simulated flow were represented along with the historical monitoring series unsatisfactorily. In Figure 4a, the flow simulations were overestimated in practically the entire series, mainly in the years 2008, 2009, 2013 and 2016. In Figure 4-b, the flow simulations were also overestimated, but in some rainy years the simulations were underestimated, as is the case for the years 2011, 2012 and 2013. As previously stated, rainfall and fluviometric data were not consistent in the validation period (2008 to 2017), which may partly explain these discrepancies. Hydrological behaviors of ungauged basins (for example, complex geological conditions and loss from the aquifer) may cause other problems which could lead to a reduction in model performance parameters (Choubin et al., 2019).

The graph of the historical series of monthly total solid discharges (simulated and observed) at the Porto Indaia Station, resulting from the simulation obtained in the monthly validation, can be seen in Figure 5.

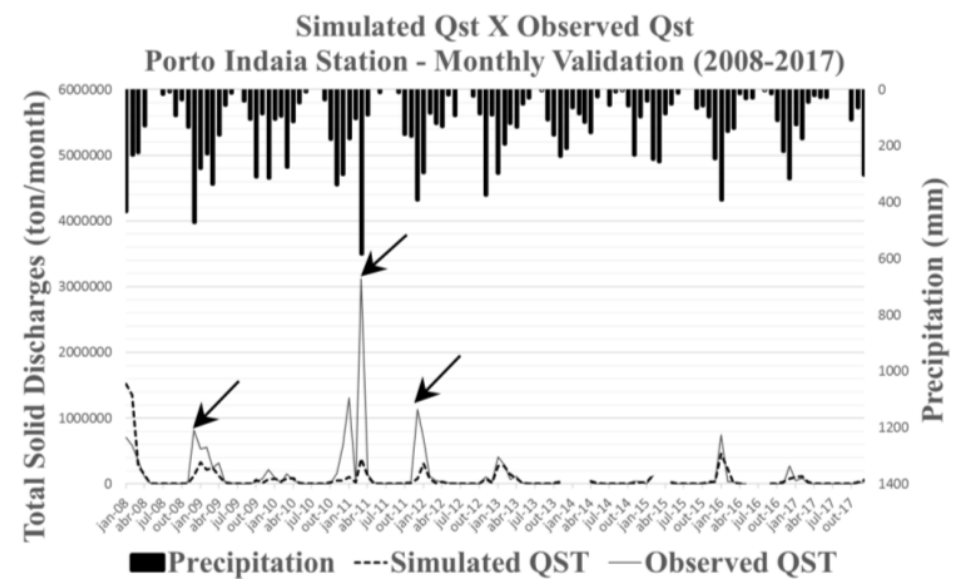

Figure 5. Total solid discharge (QST) simulation in validation - Porto Indaia Station.

The graph of the simulated results of total solid discharge in the validation stage (Figure 5) showed an inadequate adjustment, the value being underestimated in almost the entire series, mainly in the years 2009, 2011 and 2012. In the model validation, the following performance indexes for the simulation of the flow variable were obtained: Porto Indaia Station (P-factor= 0.91, $\mathrm{R}$-factor $=1.07, \mathrm{R}^{2}=0.85, \mathrm{NSE}=0.82$ and PBIAS $\left.=-20.8\right)$ and Barra do Funchal Station (P-factor $=0.82, \mathrm{R}$-factor $=0.86, \mathrm{R}^{2}=0.77, \mathrm{NSE}=0.77$ and PBIAS $=0.5$ ), and variable total solid discharge: Porto Indaia Station $\left(\mathrm{P}\right.$-factor $=0.76, \mathrm{R}$-factor $=1.04, \mathrm{R}^{2}=0.19, \mathrm{NSE}=0.16$ and PBIAS $=43.5$ ).

Although the majority of research in the literature focusing on SWAT model concludes that this model can satisfactorily estimate sediments (Duru et al., 2018), there are numerous studies on sediment modeling in which it was not possible to obtain satisfactory results (Zanin et al., 2018; Ferrigo, 2014; Strauch et al., 2013; Uzeika et al., 2012). We assume that the origin of the inconsistencies in the solid discharge simulations is due in part to the data that generated the sediment rating curve (daily sampling of solid suspended discharge - Qss, and flow measurement -Q), which presented a high dispersion along with the historical series. A possible solution would be the temporal analysis of the rating curve. Analyzing the variability of the behavior of the data (dispersion) over the historical series, it is possible to detect trends in time variations that can alter the definition of the rating curves or even define some rating curves for each time interval.

The difficulty of SWAT in estimating sediments budget are mainly associated with the limitations of the MUSLE (Modified Universal Soil Loss Equation) equation (Uzeika et al., 2012). The model's inability to capture the undulations of the landscape on slopes greater than 
$45 \%$ is considered one of these limitations (Bonumá et al., 2014).

On the other hand, the deficiency in the measure of sediment transport in overflow conditions in the river is another inconsistency related to parametrization in the SWAT model (Santini, 2020; Neitsch et al., 2011). The default method of SWAT (Bagnold method) does not guarantee the best results for the calculation of sediment transport (Yen et al.,2017); and the use of sediment rating curves elaborated with field measurements performed at low- and medium-flow rates are unable to represent the change in the behavior of the sediment flow occurring at high-flow rates (Condé, 2021).

In this study, three factors may have contributed to the overestimation of the sediment load in the Indaiá Basin: 1. The difficulty of SWAT in capturing the undulations of the landscape in the Indaiá Basin, which has a high slope in $66 \%$ of the Indaiá Basin (10\% of the area with wavy relief and 56\% with strong-wavy, mountainous or strong-mountainous relief), keeping the sediment influx instead of accounting for deposition in the relief depressions; 2 . The sediment rating curve was elaborated in a range of flow rates $\left(3\right.$ to $\left.943 \mathrm{~m}^{3} \mathrm{~s}^{-1}\right)$ less than the flow occurring in the analysis period ( 2 to $1319 \mathrm{~m}^{3} \mathrm{~s}^{-1}$ ), and is not mainly representative of the behavior of the sediment flow at higher flows, which are responsible for most of the sediment transport; 3 . The use of Bagnold's simplified equation for sediment transport, instead of the equations with approaches in the laws of physics available in SWAT.

\subsection{Distribution of Sediment Yield}

The average annual sediment yield map (ton/ha.year) of the Indaia Basin by HRU is shown in Figure 6.

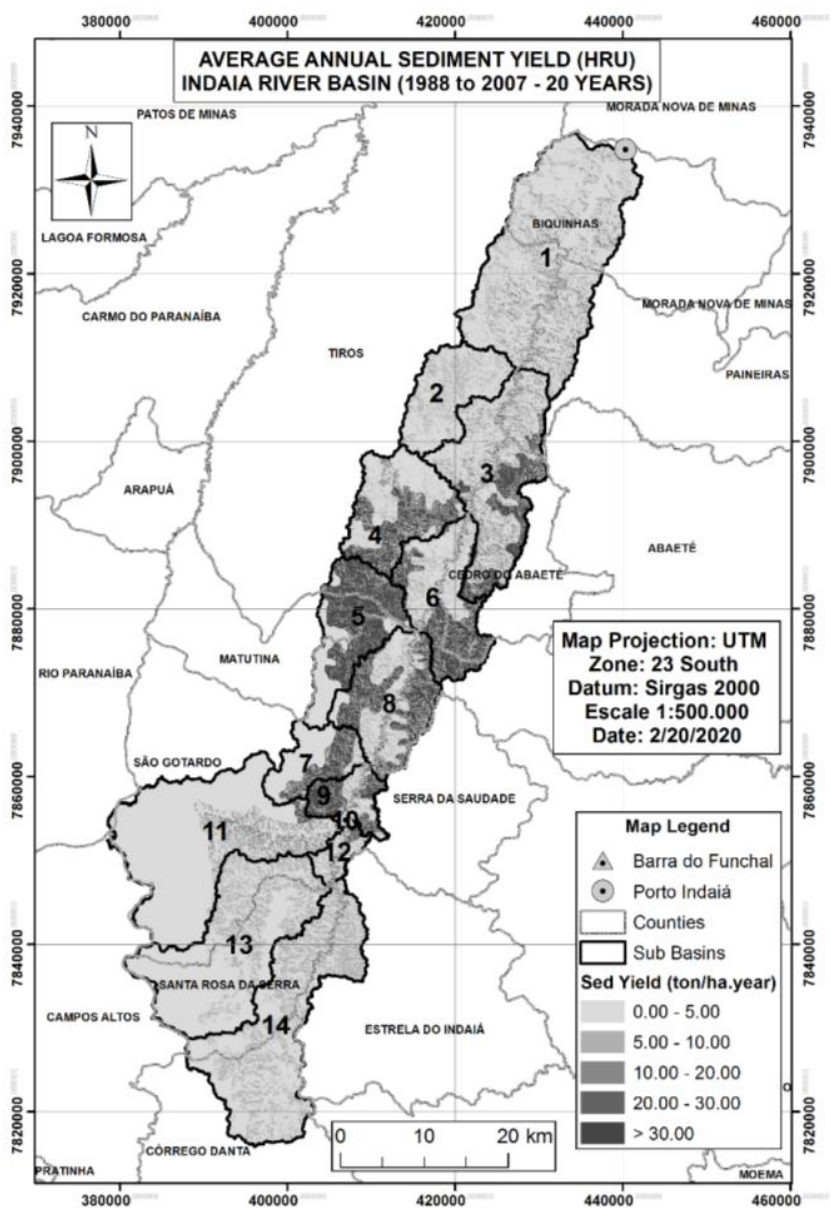

Figure 6. Average annual sediment yield in the Indaia River Basin (per HRU). 
Analyzing the figure, it can be seen that the most critical sub-basins are numbers five (5) and nine (9), followed by sub-basins eight (8), six (6), four (4), seven (7), and three (3). When viewing the maps of soil, land use and cover and slope of the basin, it is observed that the soil of sub-basins 5 and 9 is mostly litolic neossol and the land use and cover is pasture with a high slope, which contributes to the formation of sediments carried by the tributaries and from these to the channel of the Indaia River.

The result obtained from the sediment yield for the Indaia River Basin corroborates the results achieved by Creech et al. (2015), which determined that the Upper São Francisco Basins are the main sources of sediment carried into the São Francisco River channel. As the Indaia River is the main contributor to the Três Marias Reservoir, which in turn has a significant regularization function of the São Francisco River flow, understanding the amount of sediment entering this reservoir allows the CEMIG Concessionaire to better manage the sedimentation rate.

Concerning the water-resource planning and management, the results of this work allow us to identify the areas that contribute most to the sediment yield in the basin, that is, the source areas. This is important for municipal and state agencies that are responsible for territorial planning and public policies to combat environmental degradation.

\section{CONCLUSIONS}

It is concluded that the calibrated hydrological and sedimentological model in this work allowed the estimation of the sediment yield generated by water erosion in the Indaia River Basin, despite the model not having been adjusted properly. Thus, it is understood that despite the result having generated values of tons per hectare per year, it is considered that the resulting map shows an indication of the places with the highest sediment yield.

The sensitivity analysis showed that parameters related to groundwater flow showed greater sensitivity in the flow simulation, while the parameters related to MUSLE showed greater sensitivity in the simulation of the solid discharge. It is important to note that additional tests could have been performed with the inclusion and removal of parameters to improve the results.

The SWAT was able to simulate the monthly flow (runoff and base flow) satisfactorily, both in the calibration and in the model validation, presenting good quality and efficiency of the hydrological simulation. However, it did not adequately simulate the total solid discharge, mainly in the validation of the model. It is assumed that the origin of the inconsistencies in the solid discharge simulations is partly due to the data that generated the sediment rating curve (daily sampling of suspended solid discharge and flow measurement), which presented high dispersion along with the historical series. It should be noted that the quality of the modeling is associated with the quality of the input data, the algorithms used, and the elaborated sediment rating curves.

Finally, the average annual sediment yield map (ton/ha.year), generated using the calibrated hydrological and sedimentological model, indicates, in a qualitative way, a tendency for greater erosion processes to occur in the central portion of the basin, in sub-basins with less extension and greater slope. This result can be used to support decision-making related to conservation planning in the Indaia River Basin, contributing to guide public policies that mitigate environmental degradation in the study area.

\section{ACKNOWLEDGEMENT}

CEMIG (Companhia Energética de Minas Gerais), ANA (Agência Nacional de Águas) and INMET (Instituto Nacional de Meteorologia), for providing sedimentological, fluviometric, pluviometric and climatological data. ESRI (Environmental Systems Research 
Institute) for using the Toolkit that is comprised of the ArcGIS 10.x Family through Contract No. 2011 MLK 8733. CAPES (Coordenação de Aperfeiçoamento de Pessoal de Nível Superior) for promoting the Programa de Pós-graduação em Geociências Aplicadas e Geodinâmica do Instituto de Geociências (PPGGAG) of UnB (Universidade de Brasília).

\section{REFERENCES}

ABBASPOUR, K. C.; ROUHOLAHNEJAD, E.; VAGHEFI, S.; SRINIVASAN, R.; YANG, H.; KLØVE, B. A continental-scale hydrology and water quality model for Europe: Calibration and uncertainty of a high-resolution large scale SWAT model. Journal of Hydrology, v. 524, n. 5, p. 733-752, 2015. https://doi.org/10.1016/j.jhydrol.2015.03.027

ARNOLD, J. G.; KINITY, J. R.; SRINIVASAN, R.; WILLIAMS, J. R.; HANEY, E. B.; NEITSCH, S. L. Input/Output Documentation Version 2012. Texas Water Resources Institute, 2012a. Report n. 439, 650p.

ARNOLD, J. G. et al. SWAT: Model Use, Calibration, and Validation. Transactions of the ASABE, v. 55, n. 4, p. 1491-1508, 2012 b.

BAGNOLD, R. A. Bedload transport in natural rivers. Water Resources Research, v. 13, n. 2, p. 303-312, 1977. https://doi.org/10.1029/WR013i002p00303

BALDISSERA, G. C. Aplicabilidade do modelo de simulação hidrológica SWAT (Soil and Water Assessment Tool), para a bacia hidrográfica do Rio Cuiabá/MT. 2005. 148f. Dissertação (Mestrado em Física e Meio Ambiente) - Instituto de Ciências Exatas e da Terra, Universidade Federal do Mato Grosso, Cuiabá, 2005.

BOITHIAS, L.; SAUVAGE, S.; LENICA, A.; ROUX, H.; ABBASPOUR, K.C.; LARNIER, K.; DARTUS, D.; SÁNCHEZ-PÉREZ, J. M. Simulating Flash Floods at Hourly TimeStep Using the SWAT Model. Water, v. 9, p. 929, 2017. https://doi.org/10.3390/w9120929

BONUMÁ, N. B. et al. Simulating landscape sediment transport capacity by using a modified SWAT model. Journal of environmental quality, v. 43, n. 1, p. 55-66, 2014. https://doi.org/10.2134/jeq2012.0217

BRAKENSIEK, D. L. Kinematic flood routing. Transactions of the ASAE. American Society of Agricultural Engineers, v. 10, n. 3, p. 340-343, 1967. http://dx.doi.org/10.13031/2013.39668

BRASIL. Ministério das Minas e Energia. Departamento Nacional de Produção Mineral. Projeto RADAMBRASIL. Levantamento de Recursos Naturais. Rio de Janeiro: MME, 1987.

BRASIL. Ministério do Meio Ambiente. Secretaria de Recursos Hídricos. Caderno da Região Hidrográfica do São Francisco. Brasília/DF: MMA, 2006. 148p. Available at: www.mma.gov.br/estruturas/161/_publicacao/161_publicacao03032011023538.pdf. Access: 18 Feb. 2020.

BRIAK, H.; MRABET, R.; MOUSSADEK, R.; ABOUMARIA, K. Use of a calibrated SWAT model to evaluate the effects of agricultural BMPs on sediments of the Kalaya river basin (North of Morocco). International Soil and Water Conservation Research, v. 7, n. 2, p. 176-183, 2019. https://doi.org/10.1016/j.iswcr.2019.02.002 
BRIGHENTI, T. M.; BONUMÁ, N. B.; GRISON, F.; MOTA, A. A.; KOBIYAMA, M.; CHAFFE, P. L. B. Two calibration methods for modeling streamflow and suspended sediment with the swat model. Ecological Engineering, v. 127, p. 103-113, 2019a. https://doi.org/10.1016/j.ecoleng.2018.11.007

BRIGHENTI, T. M.; BONUMÁ, N. B.; SRINIVASAN, R.; CHAFFE, P. L. B. Simulating subdaily hydrological process with SWAT: a review, Hydrological Sciences Journal, v. 64, n. 12, p. 1415-1423. 2019b. https://doi.org/10.1080/02626667.2019.1642477

CARVAlHO, N. O. Hidrossedimentologia Prática. 2. ed. Rio de Janeiro: Interciência, 2008. 600 p.

CASTRO, K. B.; ROIG, H. L.; LIMA, J. E. F. W.; FERRIGO, S. Aplicação de série temporal mínima para simulação de vazões em bacia experimental do cerrado. Revista Brasileira de Cartografia, v. 68, n. 8, p. 1497-1513, 2016.

CREECH, C. T.; SIQUEIRA, R. B.; SELEGEAN, J. P.; MILLER, C. Anthropogenic impacts to the sediment budget of São Francisco River navigation channel using SWAT. International Journal of Agricultural \& Biological Engineering, v. 8, n. 3, p. 140157, 2015. http://dx.doi.org/10.3965/j.ijabe.20150803.1372.

CHOUBIN, B. et al. Streamflow regionalization using a similarity approach in ungauged basins: Application of the geo-environmental signatures in the Karkheh River Basin, Iran. Catena, v. 182, p. 104128, 2019. https://doi.org/10.1016/j.catena.2019.104128

CONDÉ, R. de C. C. Análise da integração das ferramentas de Hidrologia Espacial "cor das águas" para o monitoramento e a modelagem SWAT dos processos hidrossedimentológicos na Bacia do Rio São Francisco - Brasil. 2021. 258p. Tese (Doutorado em Geociências Aplicadas) - Instituto de Geociências, Universidade de Brasília, Brasília, 2021. 258p.

DANTAS, J. C.; SILVA, M. A.; SILVA, R. M.; VIANNA P. C. G. Simulação vazão-erosão usando o modelo SWAT para uma grande bacia da região semiárida da Paraíba. Geociências, v. 34, n. 4, p. 816-827, 2015.

DEVIA, G. K.; GANASRI, B. P.; DWARAKISH, G. S. A review on hydrological models. Aquatic Procedia, v. 4, p. 1001-1007, 2015. https://doi.org/10.1016/j.aqpro.2015.02.126

DURU, U.; ARABI, M.; WOHL, E. E. Modeling stream flow and sediment yield using the SWAT model: a case study of Ankara River basin, Turkey. Physical Geography, v. 39, n. 3, p. 264-289, 2018. https://doi.org/10.1080/02723646.2017.1342199.

FERNANDES, G. F. Estimativa de vazão e produção de sedimentos na bacia hidrográfica do rio São Francisco, utilizando o modelo SWAT. 2015. 185f. Tese (Doutorado em Geografia) - Universidade Federal de Pernambuco, Recife, 2015.

FERRIGO, S. Análise de consistência dos parâmetros do modelo SWAT obtidos por calibração automática - Estudo de caso da bacia do lago Descoberto - DF. 2014. 164f. Dissertação (Mestrado em Tecnologia Ambiental e Recursos Hídricos) Departamento de Engenharia Civil e Ambiental, Universidade de Brasília, Brasília, 2014.

FRANCESCONI, W. et al. Using the Soil and Water Assessment Tool (SWAT) to model ecosystem services: A systematic review. Journal of Hydrology, v. 535, p. 625-636, 2016. https://doi.org/10.1016/j.jhydrol.2016.01.034 
GASSMAN, P. W.; YINGKUAN, W. IJABE SWAT Special Issue: Innovative modeling solutions for water resource problems. International Journal of Agricultural and $\begin{array}{llllllll}\text { Biological Engineering, } & \text { v. } & \text { 8, } & \text { n. } & 3, & \text { p. } & 1-8,\end{array}$ https://ijabe.org/index.php/ijabe/article/view/1763.

HIMANSHU, S. K., PANDEY, A.; YADAV, B.; GUPTA, A. Evaluation of best management practices for sediment and nutrient loss control using SWAT model. Soil \& Tillage Research, v. 192, p. 42-58, 2019. https://doi.org/10.1016/j.still.2019.04.016.

HIMANSHU, S. K.; PANDEY, A.; SHRESTHA, P. Application of SWAT in an Indian river basin for modeling runoff, sediment and water balance. Environmental Earth Sciences, v. 76, n. 3, p. 1-18, 2017. https://doi.org/10.1007/s12665-016-6316-8.

KHOI, D. N. et al. Responses of river discharge and sediment load to climate change in the transboundary Mekong River Basin. Water and Environment Journal, v. 34, p. 367380, 2020. https://doi.org/10.1111/wej.12534

KRYSANOVA, V.; WHITE, M. Advances in water resources assessment with SWAT - an overview. Hydrological Sciences Journal, v. 60, n. 5, p. 771-783, 2015. https://doi.org/10.1080/02626667.2015.1029482.

MACÊDO, Í. L. Estudo de Modelos em Ambiente de Geoprocessamento para a Previsão de Erosão e Assoreamento de Reservatórios: o Caso da Bacia do Rio Indaia-UHE Três Marias, MG. 2009. 312f. Tese (Doutorado em Geotecnia) - Departamento de Engenharia Civil e Ambiental, Faculdade de Tecnologia, Universidade de Brasília, Brasília, 2009.

MALAGÓ, A.; BOURAOUI, F.; VIGIAK, O.; GRIZZETTI, B.; PASTORI, M. Modelling water and nutrient fluxes in the Danube River Basin with SWAT. Science of the Total $\begin{array}{llllll}\text { Environment, } & \text { v. } & 603-604, & \text { p. }\end{array}$ http://dx.doi.org/10.1016/j.scitotenv.2017.05.242.

MAPBIOMAS. Collection 4 of the Annual Land Use Land Cover Maps of Brazil. Available at: http://mapbiomas.org. Access: 10 Jan. 2018.

MENEZES, P. H. B. J. Estudo da Dinâmica Espaço-Temporal do Fluxo de Sedimentos a partir das Propriedades Ópticas das Águas no Reservatório de Três Marias - MG. 2013. 2013. 112f. Tese (Doutorado em Geociências Aplicadas) - Instituto de Geociências, Universidade de Brasília, Brasília/DF, 2013.

MONTEITH, J. L. Evaporation and Environment. Symposia of the Society for Experimental Biology, v. 19, p. 205-234, 1965.

MORIASI, D. N.; ARNOLD, J. G.; VAN LIEW, M. W; BINGNER, R. L.; HARMEL, R. D.; VEITH, T. L. Model evaluation guidelines for systematic quantification of accuracy in watershed simulations. Transactions of the ASABE, v. 50, n. 3, p. 885-900, 2007.

NEITSCH, S. L.; ARNOLD, J. G.; KINIRY, J. R.; WILLIAMS, J. R. Soil and Water Assessment Tool, Theoretical documentation version 2009. Temple: Blackland Research Center, 2011. Report n 406, 618p.

NUNES, G. Aplicação do modelo SWAT no estudo hidrológico e de qualidade de água da Bacia Hidrográfica do lago Paranoá - DF. 2016. 148p. Dissertação (Mestrado em Tecnologia Ambiental e Recursos Hídricos) - Departamento de Engenharia Civil e Ambiental, Universidade de Brasília, Brasília, 2016. 
PANDEY, A.; LALREMPUIA, D.; JAIN, S. K. Assessment of hydropower potential using spatial technology and SWAT modelling in the Mat River, southern Mizoram, India. Hydrological Sciences Journal, v. 60, n. 10, p. 1651-1665, 2015. https://doi.org/10.1080/02626667.2014.943669

PENMAN, H. L. Natural evaporation from open water, bare soil and grass. Proceedings of the Royal Society of London, v. 193, n. 1032, p. 120-145, 1948. https://doi.org/10.1098/rspa.1948.0037

PINTO, C. E. T.; MENEZES, P. H. B. J.; MARTINEZ, J. M.; ROIG, H. L.; VILLAR, R. A. E. Uso de imagens MODIS no monitoramento do fluxo de sedimentos no reservatório de Três Marias. Revista Brasileira de Engenharia Agrícola e Ambiental, v. 18, n. 5, p. 507-516, 2014. https://doi.org/10.1590/S1415-43662014000500007

PULIGHE, G.; BONATI, G.; COLANGELI, M.; TRAVERSO, L.; LUPIA, F.; ALTOBELLI, F.; DALLA MARTA, A.; NAPOLI, M. Predicting streamflow and nutrient loadings in a semi-arid mediterranean watershed with ephemeral streams using the SWAT model. Agronomy, v. 10, n. 2, 2020. https://doi.org/10.3390/agronomy10010002.

QIU, J.; SHEN, Z.; HUANG, M.; ZHANG, X. Exploring Effective Best Management Practices in the Miyun Reservoir Watershed, China. Ecological Engineering, v. 123, p. 30-42, 2018. https://doi.org/10.1016/j.ecoleng.2018.08.020

SANTINI, W. Caractérisation de la dynamique hydro-sédimentaire du bassin de l'Ucayali (Pérou) par une approche intégrant réseau de mesures, télédétection, et modélisation hydrologique. 2020. 471p. Tese (Doutorado) - Université Toulouse 3 Paul Sabatier, Toulouse, 2020.

SILVA, A. K. L.; SOUZA, A. M. L.; SANTOS, J. T. S.; VILLELA, J. M.; MARTORANO, L. G.; CRESTANA, S. Estimation of sediment production in oil palm expansion areas in the Amazon. Revista Brasileira Engenharia Agrícola e Ambiental, v. 22, n. 5, p. 344-348, 2018a. http://dx.doi.org/10.1590/1807-1929/agriambi.v22n5p344-348.

SILVA, M. T.; AZEVEDO, P. V.; SILVA, V. P.; SILVA, B. K.; MARIANO, E. B.; AMORIM, M. R. B. Estimativa da produção de sedimentos na bacia hidrográfica do submédio Rio São Francisco. Journal of Environmental Analysis and Progress, v. 02, n. 03, p. 203211, 2017. http://dx.doi.org/10.24221/jeap.2.3.2017.1430.203-211.

SILVA, R. M.; SANTOS, C. A. G.; SANTOS, J. Y. G. Evaluation and modeling of runoff and sediment yield for different land covers under simulated rain in a semiarid region of Brazil. International Journal of Sediment Research, v. 33, n. 2, p. 117-125, 2018b. https://doi.org/10.1016/j.ijsrc.2017.04.005.

SILVA, V. P. R.; SILVA, M. T.; SOUZA, E. P. Influence of land use change on sediment yield: a case study of the sub-middle of the São Francisco river basin. Engenharia Agrícola, v. 36 , n. 06 , p. 1005-1015, 2016. http://dx.doi.org/10.1590/1809-4430eng.agric.v36n6p1005-1015/2016

STRAUCH, M.; VOLK, M. SWAT plant growth modification for improved modeling of perennial vegetation in the tropics. Ecological Modelling, v. 269, p. 98-112, 2013. https://doi.org/10.1016/j.ecolmodel.2013.08.013

STRAUCH, M. et al. The impact of Best Management Practices on simulated streamflow and sediment load in a Central Brazilian catchment. Journal of Environmental Management, v. 127, p. S24-S36, 2013. https://doi.org/10.1016/j.jenvman.2013.01.014 
TAN, M. L. et al. A review of SWAT studies in Southeast Asia: applications, challenges and future directions. Water, v. 11, n. 5, p. 914, 2019. https://doi.org/10.3390/w11050914

TIWARI, D; TIWARI, H. L.; SAINI, R. Hydrological Modelling in Narmada Basin using Remote Sensing and GIS with SWAT model and Runoff Prediction in Patan Watershed. International Journal of Advanced Research, Ideas and Innovations in Technology, v. 4, n. 2, p. 344-352, 2018.

UPADHYAY, H.; MITTAL, H. K.; SINGH, M.; HIRAPARA, J. G. Application of SWAT Model for Estimation of Runoff in Pindwara Watershed and Assessment of its Feasibility. International Journal of Current Microbiology and Applied Sciences, v. 8, n. 6, p. 3056-3065, 2019. https://doi.org/10.20546/ijcmas.2019.806.364.

URIBE, N.; CORZO, G.; QUINTERO, M.; VAN GRIENSVEN, A.; SOLOMATINE, D. Impact of conservation tillage on nitrogen and phosphorus runoff losses in a potato crop system in Fuquene watershed, Colombia. Agricultural Water Management, v. 209, p. 62-72, 2018. https://doi.org/10.1016/j.agwat.2018.07.006.

USDA. National Engineering Handbook: section 4: hydrology. Washington: Soil Conservation Service, 1972. chap. 4-10.

UZEIKA, T. et al. Use of the SWAT model for hydro-sedimentologic simulation in a small rural watershed. Revista Brasileira de Ciência do Solo, v. 36, n. 2, p. 557-565, 2012. https://doi.org/10.1590/S0100-06832012000200025

VAN GRIENSVEN, A.; NDOMBA, P.; YALEW, S.; KILONZO, F. Critical review of SWAT applications in the upper Nile basin countries. Hydroloy and Earth System Sciences, v. 16, p. 3371-3381, 2012. https://doi.org/10.5194/hess-16-3371-2012

VIGIAK, O.; MALAGÓ, A.; BOURAOUI, F.; VANMAERCKE, M.; POESEN, J. Adapting SWAT hillslope erosion model to predict sediment concentrations and yields in large Basins. Science of the Total Environment, v. 538, p. 855-875, 2015. https://doi.org/10.1016/j.scitotenv.2015.08.095.

VIGIAK, O.; MALAGÓ, A.; BOURAOUI, F.; VANMAERCKE, M.; OBREJA, F.; POESEN, J.; HABERSACK, H.; FEHER, J.; GROSELJ, S. Modelling sediment fluxes in the Danube River Basin with SWAT. Science of The Total Environment, v. 599-600, n. 1, p. 992-1012, 2017. http://dx.doi.org/10.1016/j.scitotenv.2017.04.236.

WU, H.; CHEN, B. Evaluating uncertainty estimates in distributed hydrological modeling for the Wenjing River watershed in China by GLUE, SUFI-2, and ParaSol methods. $\begin{array}{llllll}\text { Ecological Engineering, } & \text { v. } & \text { 76, } & \text { p. }\end{array}$ https://doi.org/10.1016/j.ecoleng.2014.05.014

YEN, H. et al. Assessment of optional sediment transport functions via the complex watershed simulation model SWAT. Water, v. 9, n. 2, p. 76, 2017. https://doi.org/10.3390/w9020076

ZANIN, P. R.; BONUMA, N. B.; CORSEUIL, C. W. Hydrosedimentological modeling with SWAT using multi-site calibration in nested basins with reservoirs. RBRH, v. 23, 2018. https://doi.org/10.1590/2318-0331.231820170153 